\title{
Multiple Tick-Borne Pathogens in Ixodes ricinus Ticks Collected from Humans in Romania
}

\author{
Zsuzsa Kalmár ${ }^{1, *}$, Mirabela Oana Dumitrache ${ }^{1}$, Gianluca D'Amico ${ }^{1}$, Ioana Adriana Matei ${ }^{1,2}{ }^{(}$, \\ Angela Monica Ionică ${ }^{1,3}$, Călin Mircea Gherman ${ }^{1}\left(\mathbb{D}\right.$, Mihaela Lupșe $^{4}$ and \\ Andrei Daniel Mihalca ${ }^{1}$ \\ 1 Department of Parasitology and Parasitic Diseases, Faculty of Veterinary Medicine, University of \\ Agricultural Sciences and Veterinary Medicine Cluj-Napoca, 400372 Cluj-Napoca, Romania; \\ mirabela.dumitrache@usamvcluj.ro (M.O.D.); gianluca.damico@usamvcluj.ro (G.D.); \\ matei.ioana@usamvcluj.ro (I.A.M.); ionica.angela@usamvcluj.ro (A.M.I.); \\ calin.gherman@usamvcluj.ro (C.M.G.); amihalca@usamvcluj.ro (A.D.M.) \\ 2 Department of Microbiology, Immunology and Epidemiology, Faculty of Veterinary Medicine, \\ Calea Mănăştur, no. 3-5, 400372 Cluj-Napoca, Romania \\ 3 "Regele Mihai I al României" Life Sciences Institute, University of Agricultural Sciences and Veterinary \\ Medicine Cluj-Napoca, 3-5 Calea Mănăștur, 400372 Cluj-Napoca, Romania \\ 4 Department of Infectious Diseases, University of Medicine and Pharmacy "Iuliu Haţieganu", \\ Iuliu Moldovan 23, 400000 Cluj-Napoca, Romania; mihaela.lupse@yahoo.com \\ * Correspondence: zsuzsa.kalmar@usamvcluj.ro; Tel.: +4072-2834-993
}

Received: 20 April 2020; Accepted: 18 May 2020; Published: 19 May 2020

\begin{abstract}
Ticks are medically important vectors of infectious diseases that are able to transmit pathogens to humans and animals. Tick-borne diseases represent a major health concern, posing an increasing risk to the public health during the last century and affecting millions of people. The aim of the current study was to provide epidemiological data regarding the presence of certain tick-borne pathogens in ticks feeding on humans in Romania. Overall, 522 Ixodes ricinus ticks collected from humans were screened for six pathogens: Borrelia spp., Neoehrlichia mikurensis, Babesia spp., Coxiella spp., Bartonella spp., and Francisella tularensis. Ticks attached to humans were collected between 2013-2015 in Cluj County, Romania. Conventional, nested and quantitative PCR were used to detect specific genetic sequences of each pathogen. For identifying the infectious agents, positive samples were sequenced. The infection prevalence was $21.07 \%$ from which $8.18 \%$ were mixed infections. The detected agents were Borrelia spp., N. mikurensis and Babesia spp. The present data reveal the endemic occurrence of potentially zoonotic pathogens in Romania. Revealing the current distribution of tick-borne pathogens in ticks collected from humans may provide new insights in understanding the complex ecology of tick-borne diseases and enlightens current knowledge about the infection prevalence at local, regional and national levels.
\end{abstract}

Keywords: Ixodes ricinus; ticks; pathogens; tick-borne disease; humans

\section{Introduction}

Ticks of the Ixodidae family have medical and veterinary importance worldwide, mainly due to the transmission of tick-borne pathogens [1]. Pathogens are maintained in nature by ticks and vertebrates which may act as vectors and reservoirs of infectious agents. Important pathogens vectored by ticks, besides bacteria, are viruses and protozoa. Among the main bacterial pathogens transmitted by ticks are the causative agents of Lyme borreliosis, Borrelia burgdorferi sensu lato, and B. miyamotoi, which causes relapsing fever. Although infections with other tick-borne pathogens transmitted by Ixodes ricinus, 
such as Neoehrlichia mikurensis, several Babesia spp., Bartonella spp., Francisella tularensis, and Coxiella burnetii may cause human disease as well, they have been reported considerably less frequently.

The risk of acquiring infections with tick-borne pathogens is determined by the abundance of ticks in the specific geographical location, the density of reservoir hosts and the prevalence of infection in ticks and hosts [2]. Monitoring tick-borne pathogens in certain geographical areas is of particular importance to assess the fluctuation of human infection risks. Cluj County is situated in the north-western part of Romania, and due to the presence of hilly and mountainous relief it has a heterogeneous vegetation and a relatively high diversity of hosts for I. ricinus [3]. So far, studies conducted in Romania have evaluated the prevalence of Borrelia spp., N. mikurensis, Anaplasma spp., and Rickettsia spp. in I. ricinus [4-8]. The only study with a large dataset elaborated in Romania has evaluated the infection prevalence of B. burgdorferi s.l. in ticks collected from humans and in patients bitten by Borrelia-positive ticks [4,5].

Although there is a continuous increase in the prevalence of tick-borne diseases in Europe, few data on ticks and tick-related diseases in humans are available, while in Romania the information is even more limited. Therefore, the aim of the present study is to address the knowledge gap regarding the infection level of six different tick-borne pathogens in I. ricinus collected from human hosts. DNA samples of I. ricinus collected from humans from our previous study focused on A. phagocytophilum and Rickettsia spp. [7] were reused to assess the presence of the following tick-borne pathogens: Borrelia spp., N. mikurensis, Babesia spp., Bartonella spp., Coxiella spp. and Francisella spp.

\section{Results}

According to the morphological keys [9], a total of 522 ticks collected from humans were identified as $I$. ricinus. Only $I$. ricinus species were screened, as other tick species were very scarcely represented. Nymphs were the most common developmental stages found on humans (417/520, 79.89\%, 95\% CI: 76.23-83.10), followed by females (84/520, 16.09\%; 95\% CI: 13.19-19.49) and larvae (21/520, 4.02\%; 95\% CI: 2.65-6.07). No adult males were identified. Data regarding the overall infection prevalence of all the detected tick-borne pathogens (including A. phagocytophilum and Rickettsia spp.) in I. ricinus are detailed in Supplementary Materials 1 and 2. Here, we present the results of the current study. All the ticks were negative for Bartonella spp., Coxiella spp. and Francisella spp. In total, 110 (21.07\%) out of 522 ticks were infected with at least one pathogen (Table 1), from which $8.18 \%$ were mixed infections (Table 2). Only mixed infections with pathogens from different genera were detected. Of the collected ticks, $23.82 \%$ of females, $20.86 \%$ of nymphs and $9.52 \%$ of the larvae were infected by at least one pathogen. Significant annual differences in infection prevalence $\left(\chi^{2}=13.041\right.$, df $\left.=2, P=0.0015\right)$ were observed for nymphs with higher infection rate in the second study year.

Table 1. The prevalence of Borrelia spp., N. mikurensis and Babesia spp. in I. ricinus collected from humans.

\begin{tabular}{|c|c|c|c|c|}
\hline $\begin{array}{c}\text { Pathogen } \\
\text { Year }\end{array}$ & \multicolumn{4}{|c|}{ Prevalence $\%(+/ n ; 95 \%$ CI $)$} \\
\hline \multicolumn{5}{|l|}{ B. afzelii } \\
\hline 2014 & $6.25(1 / 16 ; 0.16-30.2)$ & $2.54(3 / 118 ; 0.53-7.25)$ & $7.14(3 / 42 ; 1.50-19.48)$ & 3.98 (7/176; 1.61-8.02) \\
\hline 2015 & $0(0 / 5)$ & $6.83(11 / 161 ; 3.46-11.90)$ & $11.54(3 / 26 ; 2.45-30.15)$ & $7.29(14 / 192 ; 4.04-11.93)$ \\
\hline Average & $4.76(1 / 21 ; 0.12-23.82)$ & $5.28(22 / 417 ; 3.51-7.86)$ & $7.14(6 / 84 ; 2.67-14.90)$ & $5.56(29 / 522 ; 3.90-7.86)$ \\
\hline 2014 & $0(0 / 16)$ & $5.08(6 / 118 ; 1.89-10.74)$ & $4.76(2 / 42 ; 0.58-16.16)$ & $4.55(8 / 176 ; 1.98-8.76)$ \\
\hline 2015 & $0(0 / 5)$ & $0.62(1 / 161 ; 0.02-3.41)$ & $0(0 / 26)$ & $0.52(1 / 192 ; 0.01-2.87)$ \\
\hline Average & $0(0 / 21)$ & $2.88(12 / 417 ; 1.65-4.96)$ & $3.57(3 / 84 ; 0.74-10.08)$ & $2.87(15 / 522 ; 1.75-4.69)$ \\
\hline
\end{tabular}


Table 1. Cont.

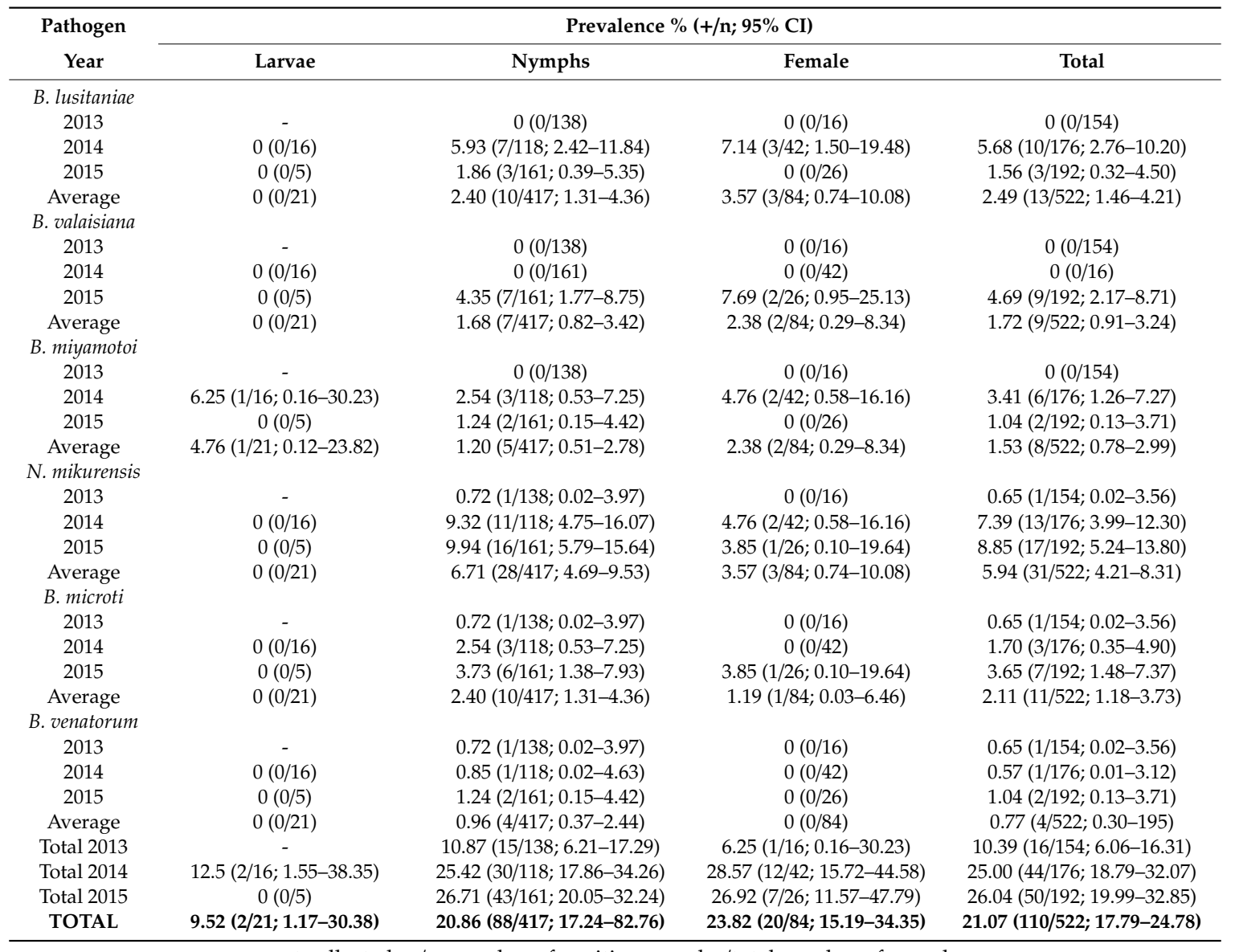

-: not collected; $+/$ n: number of positive samples/total number of samples.

The most prevalent pathogen detected was Borrelia spp. with a prevalence of $14.18 \%(74 / 522 ; 95 \% \mathrm{CI}$ : 11.45-17.43). DNA of Borrelia spp. was detected in all developmental stages: larvae (2/21, 9.52\%; 95\% CI: $1.17-30.38)$, nymphs (56/417, 13.49\%; 95\% CI: 10.54-17.12) and females (16/84, $19.05 \%$; $95 \%$ CI: 11.30-29.08) without statistical differences between stages $\left(\chi^{2}=2.2032, \mathrm{df}=2, P=0.3323\right)$. A percentage of $89.19 \%$ (66/74; 95\% CI: 79.80-95.22) of the sequenced Borrelia-positive samples showed similarity with species of the B. burgdorferi s.l. complex and $10.81 \%$ (8/74; $95 \%$ CI: 0.78-3.00) with B. miyamotoi relapsing-fever spirochetes. From the B. burgdorferi s.l. complex, four species were identified, with $B$. afzelii the most frequently detected (29/66, 43.94\%; 95\% CI: 31.74-56.7). Fifteen Borrelia-positive samples were identified as B. garinii (22.73\%; $95 \%$ CI: 13.31-34.7), followed by B. lusitaniae (13, 19.7\%; 95\% CI: 10.93-31.32) and B. valaisiana (9, 13.64\%; 95\% CI: 6.43-24.31). Among the 74 positive Borrelia spp. samples, seven $(9.46 \%$; 95\%CI: 3.89-18.52) were mixed infections with pathogens of different genera. No significant increase in the prevalence of Borrelia spp. was observed over the three years $\left(\chi^{2}=5.1185, \mathrm{df}=2, P=0.0774\right)$.

The second most frequently identified pathogen was N. mikurensis with a prevalence of $5.94 \%$ (31/522; 95\% CI: 4.21-8.31). Higher prevalence was detected in nymphs, followed by females (Table 1) $\left(\chi^{2}=2.618, \mathrm{df}=2, P=0.2701\right)$. None of the larvae were infected with this pathogen. A significant increase $\left(\chi^{2}=11.2949, \mathrm{df}=2, P=0.0035\right)$ in the prevalence of $N$. mikurensis was observed during the collection years, varying from $0.65 \%$ to $8.85 \%$, as well in nymphs $\left(\chi^{2}=11.8561, \mathrm{df}=2, P=0.0027\right)$ with infection prevalence ranging between $0.72-9.94 \%$.

DNA of Babesia spp. was detected in $2.87 \%$ of the ticks (15/522; 95\% CI: 1.75-4.69). Infection with this genus was identified in each year. None of the larvae were Babesia-positive. Two Babesia species were identified, B. microti $(2.11 \%$; $95 \%$ CI: $1.18-3.73)$ and B. venatorum $(0.77 \%$; $95 \%$ CI: $0.30-1.95)$ 
(Table 1). Among these, 14 samples were positive in nymphs (3.36\%; 95\% CI: 2.01-5.56) and one female (1.19\%; 95\% CI: 0.03-6.46) (Table 1).

Mixed infections were detected only in nymphs, with 9 ticks out of the 110 infected (Table 2) harboring co-infections with various pathogens (9/417, 2.16\%; 95\% CI: 1.14-4.05). The following species combinations were detected: B. afzelii/B. microti, B. afzelii/N. mikurensis, B. lusitaniae/N. mikurensis, B. valaisiana/N. mikurensis, N. mikurensis/B. microti, N. mikurensis/B. venatorum. A co-infection with B. valaisiana/N. mikurensis/B. venatorum was detected in one nymph (Table 2 ).

Table 2. Multiple infections with Borrelia spp., N. mikurensis and Babesia spp. in I. ricinus collected from humans in Romania.

\begin{tabular}{|c|c|c|c|c|}
\hline \multirow{2}{*}{ Pathogens } & \multicolumn{4}{|c|}{ Prevalence $\%(+/ n ; 95 \%$ CI $)$} \\
\hline & 2013 & 2014 & 2015 & Total \\
\hline B. afzelii + B. microti & $\begin{array}{c}6.25(1 / 16 \\
0.16-30.23)\end{array}$ & - & - & $0.91(1 / 110 ; 0.02-4.96)$ \\
\hline B. afzelii + N. mikurensis & - & - & $2(1 / 50 ; 0.05-10.65)$ & $0.91(1 / 110 ; 0.02-4.96)$ \\
\hline B. garinii $+N$. mikurensis & - & $4.55(2 / 44 ; 0.56-15.47$ & - & $1.82(2 / 110 ; 0.22-6.41)$ \\
\hline B. lusitaniae $+N$. mikurensis & - & $2.27(1 / 44 ; 0.06-12.02)$ & - & $0.91(1 / 110 ; 0.02-4.96)$ \\
\hline B. valaisiana $+N$. mikurensis & - & 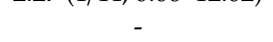 & $2(1 / 50 ; 0.05-10.65)$ & $0.91(1 / 110 ; 0.02-4.96)$ \\
\hline $\begin{array}{c}\text { B. valaisiana }+N \text {. mikurensis }+ \\
\text { B. venatorum }\end{array}$ & - & - & $2(1 / 50 ; 0.05-10.65)$ & $0.91(1 / 110 ; 0.02-4.96)$ \\
\hline N. mikurensis $+B$. microti & - & - & $2(1 / 50 ; 0.05-10.65)$ & $0.91(1 / 110 ; 0.02-4.96)$ \\
\hline N. mikurensis $+B$. venatorum & - & $2.27(1 / 44 ; 0.06-12.02)$ & - & $0.91(1 / 110 ; 0.02-4.96)$ \\
\hline TOTAL & $\begin{array}{r}6.25(1 / 16 \\
0.16-30.23)\end{array}$ & $9.09(4 / 44 ; 2.53-21.67)$ & $8(4 / 50 ; 2.22-19.23)$ & $8.18(9 / 110 ; 3.81-14.96)$ \\
\hline
\end{tabular}

-: not detected; +/n: number of co-infected samples/total number of positive samples with at least one pathogen.

\section{Discussion}

Studies on the presence and distribution of some tick-borne pathogens in humans and ticks collected from humans are scarce. Nonetheless, the national monitoring system and reporting is still absent in certain European countries. Romania has a high climatic and habitat heterogeneity favorable for the tick vectors and for developing vector-borne diseases and thus it is increasingly a focus of concern in our country. Therefore, the presence of previously unknown tick-borne pathogens in questing [10-15] and engorged ticks collected from the wild hosts have been reported [3,16-23]. The results of the present study highlight the common occurrence of tick-borne pathogens in I. ricinus collected from humans as well. Our data on prevalence is in line with reported statistics in certain European studies on ticks collected from humans [8,24-26]. In the same study period, Andersson et al. [8] reported a slightly lower average infection rate of certain tick-borne pathogens in I. ricinus collected from humans in another Romanian county (Sibiu); however, some species remained undetected (B. lusitaniae, Babesia spp.). Variations may possibly be explained by differences in sampling areas or even the sensitivity of the employed pathogen detection method.

The reported prevalence of B. burgdorferi s.l. infection in I. ricinus collected from humans in the present study (12.64\%) is similar to the mean overall prevalence of $13.7 \%$ in Europe [27]. B. afzelii, mainly associated with rodents, and B. garinii, associated with birds, were also the most frequently detected spirochete species in previous Romanian studies [3,4,8,10-12,15]. The higher prevalence of B. afzelii might be related to the abundance of rodent-based enzootic cycles in the investigated area. It is known that the distribution and prevalence of Borrelia spp. in ticks show significant temporal and spatial variations. However, the infection prevalence of three spirochete species responsible for clinical diseases in humans, B. afzelii, B. garinii and B. valaisiana, was relatively in accordance with the pervious report elaborated by Briciu et al. [4]. In I. ricinus collected from humans in the same study area, a slightly higher infection rate was observed for B. lusitaniae, with an infection prevalence increasing in time and ranging between $0.19-2.49 \%$ (2010 vs. 2013-2015). The variations in prevalence of this spirochete species may be a result of climate change, since favorable conditions might increase 
the reservoir host density. B. lusitaniae is mainly associated with lizard hosts (Lacerta agilis, L. viridis), commonly found throughout our study areas [28].

Despite the sporadic geographic distribution of the relapsing fever group agent transmitted by I. ricinus, B. miyamotoi has been detected in several European countries since its first report in questing I. ricinus in Romania [13]. Regardless of the low number of case studies on B. miyamotoi infection, certain epidemiological surveys report co-infections with other spirochete species, probably due to the overlap of endemic areas for B. miyamotoi with species from B. burgdorferi s.l. complex. The existence of this spirochete was also confirmed in small mammals in our county [3] and in I. ricinus collected from humans in another Romanian county in the same study period [8]. Nonetheless, no human cases of B. miyamotoi infection have been reported so far in Romania.

Larvae of I. ricinus pose a potential infection risk and are able to transmit B. burgdorferi s.l. Moreover, a potentially higher contribution of larvae to the transmission of $B$. miyamotoi spirochetes to humans has been shown [29]. According to previous studies, larvae are responsible for 4-21.6\% of human tick bites in Romania [4]. However, a significant number of larval ticks are not detected by people due to their size. In the present study the infection prevalence of Borrelia in larvae was $9.52 \%$, shared equally by two species, B. afzelii and B. miyamotoi. The transovarial transmission of these spirochetes was demonstrated in previous studies [30,31], although it is generally considered to be low [30,31]. Despite this, there are multiple reports of Borrelia spp. in questing larvae of I. ricinus [12,30,32]. However, the detection of spirochetes DNA does not necessarily imply the viability of these bacteria.

Mixed infection with Borrelia spp./N. mikurensis seems to be common in I. ricinus [33]. N. mikurensis was the second most abundant bacterial species in our study. This emerging tick-borne pathogen transmitted by I. ricinus ticks poses a still unclear risk to public health. It is considered the responsible agent for neoehrlichiosis, a disease causing a systemic inflammatory infection in immunocompromised patients. Studies on the presence of N. mikurensis in I. ricinus ticks collected from humans across Europe reported prevalence between $0.5-8.1 \%$. However, in Central Europe the infection incidence occurs in $6 \%$ of I. ricinus with an overall infection prevalence of $6.2 \%$ [8]. Human cases of infection with this pathogen have never been reported in our country; nonetheless, the first incidence of infection was reported in one I. ricinus tick collected from a patient [34], particularly, the N. mikurensis-positive tick was co-infected with B. afzelii. Recently, the same author [8] reported a slightly lower infection prevalence $(1.7 \%)$ in ticks collected from humans in central part of Romania in the same study period.

Data on the prevalence of Babesia spp. in I. ricinus ticks collected from humans vary considerably. Babesiosis affects animals and humans and is transmitted by ticks. Human babesiosis in Europe is caused mainly by $B$. divergens, B. venatorum and occasionally by B. microti [35]. To date, no infection with Babesia spp. in I. ricinus collected from humans have been reported in Romania. While the reservoir role of B. venatorum is the roe deer, this species was also reported in questing I. ricinus ticks, wild ungulates and in ticks originating from dogs $[36,37]$. The pathogenic B. microti, reported in several European countries, is identified foremost in the present study in I. ricinus collected from humans. In Romania, other Babesia species have been reported in equines, dogs [36], I. ricinus collected from cattle [38], bats [33], roe deer and goats [39]. However, infection rate data are scarce and further studies are needed regarding the potential medical importance of Babesia spp. as a human pathogen in Romania.

Bartonella spp. was described to cause afebrile bacteraemia in humans and animals [40]. Certain animal-associated Bartonella spp. species were isolated from blood of patients bitten by ticks, I. ricinus [41-45], bats and their ticks $[22,46,47]$. Other bacterial pathogens causing tick-borne diseases, such as F. tularensis (causing tularemia) and C. burnetii (causing $Q$ fever) have a wide spectrum of hosts including livestock, pets, birds, reptiles, wildlife and have also been detected in I. ricinus with relatively low prevalence. However, to our knowledge, only one study reports the presence of F. tularensis DNA in I. ricinus collected from roe deer and goats in Romania [39]. Epidemiological studies from certain European countries [48,49] show that the infection prevalence with these pathogens is relatively low. However, the role of I. ricinus in the transmission of the pathogens is debated $[50,51]$. 
The lack of Bartonella spp., Francisella spp. and Coxiella spp. in I. ricinus collected from humans in Romania in the present study may suggest that the infection risk with these tick-borne pathogens is very low but not negligible, which may be explained by the focal occurrence of these pathogens.

The present results revealed a variety of human pathogenic bacterial co-infections in ticks attached to humans. Molecular studies showed that multiple infections occur from $3.2 \%$ to $45 \%$ of I. ricinus ticks and have a major impact in bacterial fitness, and they may generate increased bacterial burden [52-54]. Frequently reported co-infections may result from feeding of ticks on one or multiple hosts carrying different pathogens. In the present study, Borrelia spp. were present in most of the co-infections. Meta-analysis studies focusing on the infection prevalence of tick-borne pathogens in I. ricinus ticks have shown that co-infections with the combination of Borrelia spp./N. mikurensis and Borrelia spp./Babesia spp. are relatively rare. In a small-scale study from 2019, Borrelia spp. and N. mikurensis, respectively Borrelia spp. and Babesia spp., occurred together in less than 1\% of I. ricinus collected from Denmark [53]. The co-occurrence of different pathogens suggests that I. ricinus feeds on multiple hosts of diverse species during their life cycle.

Tick-borne pathogens showed different patterns over the years. Although the infection prevalence of the detected pathogens altered between the years in the present study, with the exclusion of B. miyamotoi, the presence of the species did not change with time. While B. miyamotoi reached the highest infection prevalence in the second study year, it was not detected over all the years. The DNA of this pathogen in the first year was not recorded. Significant annual differences were observed for $N$. mikurensis with a higher infection rate in the second study year. The recorded prevalence rates of B. burgdorferi s.l. and Babesia spp. had a continuous increase in time, without significant annual differences. A similar trend was observed for co-infections. The pathogen species diversity, the number of co-infections and pathogen associations have been increasing over the years. Certain parameters can potentially affect pathogen associations. Climate factors and social and environmental drivers significantly affect the distribution and prevalence of tick-borne diseases $[55,56]$. Changes in these factors influence the vector population, reservoir host spectrum density and tick-borne pathogen reproduction rates, which may contribute to an increased risk of human infection with pathogens.

\section{Materials and Methods}

\subsection{Tick Collection and Species Identification}

During 2013-2015, ticks from humans from Cluj-Napoca and surroundings were collected by personnel from a healthcare center (Infectious Diseases Clinic and Emergency Hospital).

A questionnaire regarding the time and exposure place was completed by each tick-bitten patient. Collected ticks were stored at $-70^{\circ} \mathrm{C}$ until further analysis and were referred to our laboratory for species identification based on morphological features using dichotomous keys [9] and molecular investigation of pathogens.

\subsection{DNA Isolation}

Genetic material isolation was performed individually from each I. ricinus tick using a commercial DNA extraction kit (Isolate II Genomic DNA kit; Bioline, London, UK) according to the manufacturer's instructions. In order to identify possible cross-contamination, negative controls were used in each sample set during the procedure.

\subsection{Tick-Borne Pathogen Detection}

DNA samples were assessed for the presence of the following tick-borne pathogens: Borrelia spp., N. mikurensis, Babesia spp., Bartonella spp., Coxiella spp. and Francisella spp. Multiplex quantitative polymerase chain reaction (mqPCR) was used for evaluating the presence of Borrelia spp. in ticks. The gene encoding the outer surface protein A (ospA) was targeted for B. burgdorferi s.l. and a part of the flagellin B (flab) gene for B. miyamotoi. For N. mikurensis a simple quantitative PCR (qPCR) was 
performed. Borrelia spp. and N. mikurensis positive samples obtained by mqPCR and qPCR were amplified by convPCR using the primers and protocols described in Table 3. A nested-PCR (nPCR) amplifying the $18 \mathrm{~S}$ rDNA of Babesia spp. was used in the screening. The detection of Bartonella spp., C. burnetii and Francisella spp. DNA was carried out by conventional-PCR (convPCR) assays. Targeted genes and protocols for each pathogen are described in Table 3. The qPCR reactions were performed in CFX96 Touch ${ }^{\mathrm{TM}}$ Real-Time PCR detection system (Bio-Rad, London, UK) using IQ Multiplex Powermix (Bio-Rad) in a final volume of $20 \mu \mathrm{L}$. The final volume of convPCR and nPCR was $25 \mu \mathrm{L}$; the reaction mixture contained 2x Red PCR master Mix (Rovalab GmBH, Teltow, Germany). The convPCR and nPCR were performed in T100 ${ }^{\mathrm{TM}}$ Thermal Cycler (Bio-Rad). For quality control of PCR reactions, negative and positive controls were used.

Table 3. Targeted genes and primers used for the screening of tick-borne pathogens.

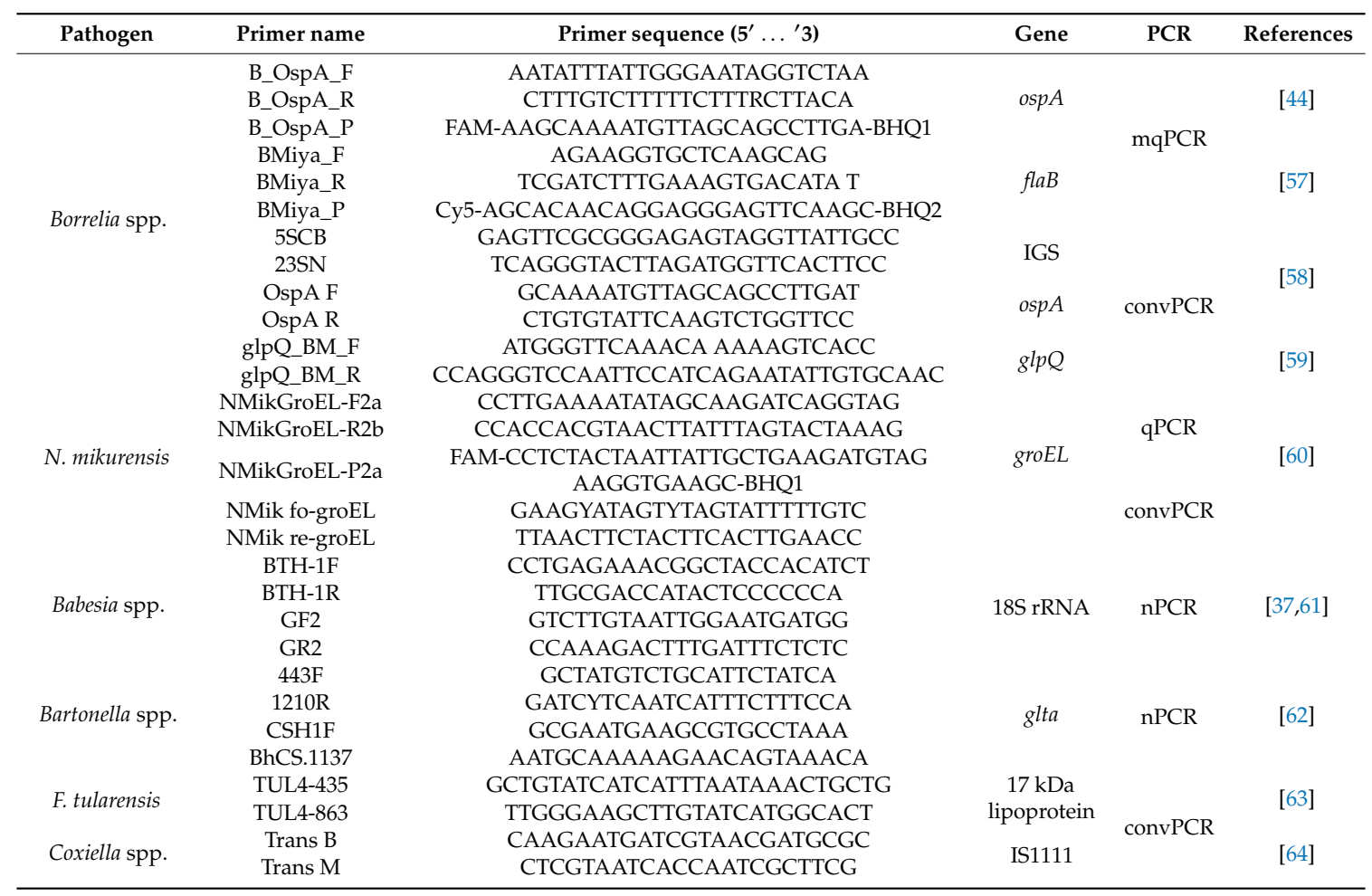

mqPCR-multiplex-quantitative PCR, convPCR — conventional PCR, qPCR—quantitative PCR, nPCR nested PCR.

\subsection{DNA Sequencing}

All the nPCR and convPCR-positive samples were sequenced at Macrogen Inc., Amsterdam, Netherlands. Nucleotide sequences were compared with those available in GenBank ${ }^{\mathrm{TM}}$ using Basic Local Alignment Search Tool (BLAST) analysis and were submitted to GenBank under accession numbers MT145337-MT145340, MT345113, MT345115-MT345116, МT345158 and MT345316-MT345317.

\subsection{Statistical Analysis}

Epi Info ${ }^{\mathrm{TM}} 2000$ software (https://www.cdc.gov/epiinfo/) was used for statistical calculations. The infection prevalence of each pathogen and the $95 \%$ confidence interval were calculated and infection prevalence differentiated by developmental stages was analyzed using a chi-squared independence test.

\section{Conclusions}

The present survey serves as a status report for the north-western part of Romania and a three-year follow-up survey showing an increasing trend in the annual incidence of tick-borne pathogens in I. ricinus. We found that co-infections with different species of tick-associated pathogens are 
relatively common and therefore should be regarded in the future diagnosis of tick-borne diseases. Consequently, due to the lack of information on human infections with tick-borne pathogens in our country, the implementation of molecular diagnosis methods as a routine diagnosis assay is needed.

Supplementary Materials: The following are available online at http://www.mdpi.com/2076-0817/9/5/390/s1, Table S1: Overall prevalence of tick-borne pathogens in I. ricinus ticks collected from humans, Table S2: Co-infections with different tick-borne pathogens in I. ricinus ticks collected from humans in Romania.

Author Contributions: Conceptualization, Z.K.; data curation, A.D.M.; funding acquisition, Z.K.; investigation, Z.K., M.O.D., G.D., I.A.M. and M.L.; methodology, Z.K.; project administration, Z.K. and A.D.M.; writing-original draft, Z.K.; writing—review \& editing, M.O.D., A.M.I., C.M.G., M.L. and A.D.M. All authors have read and agreed to the published version of the manuscript.

Funding: This work was supported by a grant of Ministry of Research and Innovation, CNCS-UEFISCDI, project number PN-III-P1-1.1-PD-2016-0974, within PNCDI III.

Acknowledgments: We would like to present our gratitude and thanks for the support of our collaborators from Infectious Diseases Clinic and Emergency Hospital Cluj-Napoca, Romania.

Conflicts of Interest: The authors declare no conflicts of interest.

\section{References}

1. Dantas-Torres, F.; Otranto, D. Best Practices for Preventing Vector-Borne Diseases in Dogs and Humans. Trends Parasitol. 2016, 32, 43-55.

2. Mihalca, A.D.; Sándor, A.D. The role of rodents in the ecology of Ixodes ricinus and associated pathogens in central and Eastern Europe. Front. Cell. Infect. Microbiol. 2013, 4, 3-5.

3. Kalmár, Z.; Sándor, A.D.; Matei, I.A.; Ionică, A.; D’Amico, G.; Gherman, C.M.; Mihalca, A.D. Borrelia spp. in small mammals in Romania. Parasit. Vectors 2019, 12, 1-6.

4. Briciu, V.T.; Meyer, F.; Sebah, D.; Ţǎţulescu, D.F.; Coroiu, G.; Lupşe, M.; Carstina, D.; Mihalca, A.D.; Hizo-Teufel, C.; Klier, C.; et al. Real-time PCR-based identification of Borrelia burgdorferi sensu lato species in ticks collected from humans in Romania. Ticks Tick Borne Dis. 2014, 5, 575-581.

5. Briciu, V.T.; Sebah, D.; Coroiu, G.; Lupşe, M.; Cârstina, D.; Ţăţulescu, D.F.; Mihalca, A.D.; Gherman, C.M.; Leucuţa, D.; Meyer, F.; et al. Immunohistochemistry and real-time PCR as diagnostic tools for detection of Borrelia burgdorferi sensu lato in ticks collected from humans. Exp. Appl. Acarol. 2016, 69, 49-60.

6. Briciu, V.T.; Flonta, M.; Ţăţulescu, D.F.; Meyer, F.; Sebah, D.; Cârstina, D.; Mihalca, A.D.; Gherman, C.M.; Hizo-Teufel, C.; Huber, I.; et al. Clinical and serological one-year follow-up of patients after the bite of Ixodes ricinus ticks infected with Borrelia burgdorferi sensu lato. Infect. Dis. 2017, 49, 277-285.

7. Matei, I.A.; Kalmár, Z.; Lupşe, M.; D’Amico, G.; Ionică, A.M.; Dumitrache, M.O.; Gherman, C.M.; Mihalca, A.D. The risk of exposure to rickettsial infections and human granulocytic anaplasmosis associated with Ixodes ricinus tick bites in humans in Romania: A multiannual study. Ticks Tick Borne Dis. 2017, 8, 375-378.

8. Andersson, M.O.; Marga, G.; Banu, T.; Dobler, G.; Chitimia-Dobler, L. Tick-borne pathogens in tick species infesting humans in Sibiu County, central Romania. Parasitol. Res. 2018, 117, 1591-1597.

9. Otranto, D.; Dantas-Torres, F.; Santos-Silvia, M.M. Ixodes ricinus (Linnaeus, 1758). In Ticks of Europe and North Africa, a guide to species identification; Estrada-Peña, A., Mihalca, A.D., Petney, T., Eds.; Springer: Berlin, Germany, 2017; pp. 189-195.

10. Coipan, E.C.; Vladimirescu, A.F. First report of lyme disease spirochetes in ticks from Romania (Sibiu County). Exp. Appl. Acarol. 2010, 52, 193-197.

11. Coipan, E.C.; Vladimirescu, A.F. Ixodes ricinus ticks (Acari: Ixodidae): Vectors for Lyme disease spirochetes in Romania. Exp. Appl. Acarol. 2011, 54, 293-300.

12. Kalmár, Z.; Mihalca, A.D.; Dumitrache, M.O.; Gherman, C.M.; Magdaş, C.; Mircean, V.; Oltean, M.; Domşa, C.; Matei, I.A.; Mărcuţan, D.I.; et al. Geographical distribution and prevalence of Borrelia burgdorferi genospecies in questing Ixodes ricinus from Romania: A countrywide study. Ticks Tick Borne Dis. 2013, 4, 403-408.

13. Kalmár, Z.; Sprong, H.; Mihalca, A.D.; Gherman, C.M.; Dumitrache, M.O.; Coipan, E.C.; Fonville, M.; Cozma, V. Borrelia miyamotoi and Candidatus Neoehrlichia mikurensis in Ixodes ricinus ticks, Romania. Emerg. Infect. Dis. 2016, 22, 550-551. 
14. Matei, I.A.; Kalmár, Z.; Magdaş, C.; Magdaş, V.; Toriay, H.; Dumitrache, M.O.; Ionică, A.M.; D’Amico, G.; Sándor, A.D.; Mărcuţan, D.I.; et al. Anaplasma phagocytophilum in questing Ixodes ricinus ticks from Romania. Ticks Tick Borne Dis. 2015, 6, 408-413.

15. Raileanu, C.; Moutailler, S.; Pavel, I.; Porea, D.; Mihalca, A.D.; Savuta, G.; Vayssier-Taussat, M. Borrelia diversity and co-infection with other tick-borne pathogens in ticks. Front. Cell. Infect. Microbiol. 2017, 7, 1-12.

16. Gherman, C.M.; Sándor, A.D.; Kalmár, Z.; Marinov, M.; Mihalca, A.D. First report of Borrelia burgdorferi sensu lato in two threatened carnivores: The marbled polecat, Vormela peregusna and the European mink, Mustela lutreola (Mammalia: Mustelidae). BMC Vet. Res. 2012, 8, 2-5.

17. Patiu, A.I.; Matei, I.A.; Mihalca, A.D.; D’Amico, G.; Dumitrache, M.O.; Kalmár, Z.; Sándor, A.D.; Lefkaditis, M.; Gherman, C.M.; Cozma, V. Zoonotic pathogens associated with Hyalomma aegyptium in endangered tortoises: Evidence for host-switching behaviour in ticks? Parasit. Vectors 2012, 5, 5-10.

18. Dumitrache, M.O.; Paştiu, A.I.; Kalmár, Z.; Mircean, V.; Sándor, A.D.; Gherman, C.M.; Peştean, C.; Mihalca, A.D.; Cozma, V. Northern white-breasted hedgehogs Erinaceus roumanicus as hosts for ticks infected with Borrelia burgdorferi sensu lato and Anaplasma phagocytophilum in Romania. Ticks Tick Borne Dis. 2013, 4, 214-217.

19. Dumitrache, M.O.; Matei, I.A.; Ionice, A.M.; Kalmár, Z.; D'Amico, G.; Sikó-Barabási, S.; Ionescu, D.T.; Gherman, C.M.; Mihalca, A.D. Molecular detection of Anaplasma phagocytophilum and Borrelia burgdorferi sensu lato genospecies in red foxes (Vulpes vulpes) from Romania. Parasit. Vectors 2015, 8, 1-5.

20. Mărcuţan, I.D.; Kalmár, Z.; Ionică, A.M.; D’Amico, G.; Mihalca, A.D.; Vasile, C.; Sándor, A.D. Spotted fever group rickettsiae in ticks of migratory birds in Romania. Parasit. Vectors 2016, 9, 3-9.

21. Corduneanu, A.; Hrazdilová, K.; Sándor, A.D.; Matei, I.A.; Ionică, A.M.; Barti, L.; Ciocănău, M.A.; Mǎntoiu, D.Ş.; Coroiu, I.; Hornok, S.; et al. Babesia vesperuginis, a neglected piroplasmid: New host and geographical records, and phylogenetic relations. Parasit. Vectors 2017, 10, 1-8.

22. Corduneanu, A.; Sándor, A.D.; Ionică, A.M.; Hornok, S.; Leitner, N.; Bagó, Z.; Stefke, K.; Fuehrer, H.P.; Mihalca, A.D. Bartonella DNA in heart tissues of bats in central and eastern Europe and a review of phylogenetic relations of bat-associated bartonellae. Parasit. Vectors 2018, 11, 1-7.

23. Matei, I.A.; D’Amico, G.; Ionică, A.M.; Kalmár, Z.; Corduneanu, A.; Sándor, A.D.; Fiţ, N.; Bogdan, L.; Gherman, C.M.; Mihalca, A.D. New records for Anaplasma phagocytophilum infection in small mammal species. Parasit. Vectors 2018, 11, 1-6.

24. Otranto, D.; Dantas-Torres, F.; Giannelli, A.; Latrofa, M.S.; Cascio, A.; Cazzin, S.; Ravagnan, S.; Montarsi, F.; Zanzani, S.A.; Manfredi, M.T.; et al. Ticks infesting humans in Italy and associated pathogens. Parasit. Vectors 2014, 7, 1-9.

25. Battisti, E.; Zanet, S.; Boraso, F.; Minniti, D.; Giacometti, M.; Duscher, G.G.; Ferroglio, E. Survey on tick-borne pathogens in ticks removed from humans in Northwestern Italy. Vet. Parasitol. Reg. Stud. Reports 2019, 18, 100352.

26. Lernout, T.; De Regge, N.; Tersago, K.; Fonville, M.; Suin, V.; Sprong, H. Prevalence of pathogens in ticks collected from humans through citizen science in Belgium. Parasit. Vectors 2019, 12, 1-11.

27. Rizzoli, A.; Hauffe, H.C.; Carpi, G.; Vourc'h, G.I.; Neteler, M.; Rosà, R. Lyme borreliosis in Europe. Euro Surveill. 2011, 16, 1-8.

28. Cogălniceanu, D.; Rozylowicz, L.; Székely, P.; Samoilă, C.; Stănescu, F.; Tudor, M.; Székely, D.; Iosif, R. Diversity and distribution of reptiles in Romania. ZooKeys 2013, 341, 49-76.

29. Van Duijvendijk, G.; Coipan, C.; Wagemakers, A.; Fonville, M.; Ersöz, J.; Oei, A.; Földvári, G.; Hovius, J.; Takken, W.; Sprong, H. Larvae of Ixodes ricinus transmit Borrelia afzelii and B. miyamotoi to vertebrate hosts. Parasit. Vectors 2016, 9, 1-7.

30. Hauck, D.; Jordan, D.; Springer, A.; Schunack, B.; Pachnicke, S.; Fingerle, V.; Strube, C. Transovarial transmission of Borrelia spp., Rickettsia spp. and Anaplasma phagocytophilum in Ixodes ricinus under field conditions extrapolated from DNA detection in questing larvae. Parasit. Vectors 2020, 13, 1-11.

31. Wagemakers, A.; Staarink, P.J.; Sprong, H.; Hovius, J.W.R. Borrelia miyamotoi: A widespread tick-borne relapsing fever spirochete. Trends Parasitol. 2015, 31, 260-269.

32. Jensen, P.M.; Christoffersen, C.S.; Moutailler, S.; Michelet, L.; Klitgaard, K.; Bødker, R. Transmission differentials for multiple pathogens as inferred from their prevalence in larva, nymph and adult of Ixodes ricinus (Acari: Ixodidae). Exp. Appl. Acarol. 2017, 71, 171-182. 
33. Richter, D.; Matuschka, F.R. “Candidatus Neoehrlichia mikurensis,” Anaplasma phagocytophilum, and Lyme Disease spirochetes in questing European vector ticks and in feeding ticks removed from people. J. Clin. Microbiol. 2012, 50, 943-947.

34. Andersson, M.; Zaghdoudi-Allan, N.; Tamba, P.; Stefanache, M.; Chitimia, L. Co-infection with “Candidatus Neoehrlichia mikurensis" and Borrelia afzelii in an Ixodes ricinus tick that has bitten a human in Romania. Ticks Tick Borne Dis. 2014, 5, 706-708.

35. Yabsley, M.J.; Shock, B.C. Natural history of Zoonotic Babesia: Role of wildlife reservoirs. Int. J. Parasitol. Parasites Wildl. 2013, 2, 18-31.

36. Imre, M.; Farkas, R.; Ilie, M.S.; Imre, K.; Dărăbuş, G. Survey of babesiosis in symptomatic dogs from Romania: Occurrence of Babesia gibsoni associated with breed. Ticks Tick Borne Dis. 2013, 4, 500-502.

37. Zintl, A.; Finnerty, E.J.; Murphy, T.M.; De Waal, T.; Gray, J.S. Babesias of red deer (Cervus elaphus) in Ireland. Vet. Res. 2011, 42, 1-6.

38. Ionita, M.; Silaghi, C.; Mitrea, I.L.; Edouard, S.; Parola, P.; Pfister, K. Molecular detection of Rickettsia conorii and other zoonotic spotted fever group rickettsiae in ticks, Romania. Ticks Tick Borne Dis. 2016, 7, 150-153.

39. Paduraru, O.A.; Buffet, J.P.; Cote, M.; Bonnet, S.; Moutailler, S.; Paduraru, V.; Femenia, F.; Eloit, M.; Savuta, G.; Vayssier-Taussat, M. Zoonotic transmission of pathogens by Ixodes ricinus ticks, Romania. Emerg. Infect. Dis. 2012, 18, 2089-2090.

40. Angelakis, E.; Raoult, D. Pathogenicity and treatment of Bartonella infections. Int. J. Antimicrob. Agents 2014, $44,16-25$.

41. Regier, Y.; Ballhorn, W.; Kempf, V.A.J. Molecular detection of Bartonella henselae in 11 Ixodes ricinus ticks extracted from a single cat. Parasit. Vectors 2017, 10, 1-5.

42. Pawełczyk, A.; Bednarska, M.; Kowalska, J.D.; Uszyńska-Kałuża, B.; Radkowski, M.; Welc-Falęciak, R. Seroprevalence of six pathogens transmitted by the Ixodes ricinus ticks in asymptomatic individuals with HIV infection and in blood donors. Sci. Rep. 2019, 9, 1-10.

43. Corrain, R.; Drigo, M.; Fenati, M.; Menandro, M.L.; Mondin, A.; Pasotto, D.; Martini, M. Study on Ticks and Tick-Borne Zoonoses in Public Parks in Italy. Zoonoses Public Health 2012, 59, 468-476.

44. Heylen, D.; Tijsse, E.; Fonville, M.; Matthysen, E.; Sprong, H. Transmission dynamics of Borrelia burgdorferi s.l. in a bird tick community. Environ. Microbiol. 2013, 15, 663-673.

45. Sytykiewicz, H.; Karbowiak, G.; Werszko, J.; Czerniewicz, P.; Sprawka, I.; Mitrus, J. Molecular screening for Bartonella henselae and Borrelia burgdorferi sensu lato co-existence within Ixodes ricinus populations in central and eastern parts of Poland. Ann. Agric. Environ. Med. 2012, 19, 451-456.

46. Hornok, S.; Szoke, K.; Meli, M.L.; Sándor, A.D.; Görföl, T.; Estók, P.; Wang, Y.; Tu, V.T.; Kováts, D.; Boldogh, S.A.; et al. Molecular detection of vector-borne bacteria in bat ticks (Acari: Ixodidae, Argasidae) from eight countries of the Old and New Worlds. Parasit. Vectors 2019, 12, 1-7.

47. Hornok, S.; Szöke, K.; Kováts, D.; Estók, P.; Görföl, T.; Boldogh, S.A.; Takács, N.; Kontschán, J.; Földvári, G.; Barti, L.; et al. DNA of piroplasms of ruminants and dogs in ixodid bat ticks. PLoS ONE 2016, 11, 1-14.

48. Sprong, H.; Tijsse-Klasen, E.; Langelaar, M.; De Bruin, A.; Fonville, M.; Gassner, F.; Takken, W.; Van Wieren, S.; Nijhof, A.; Jongejan, F.; et al. Prevalence of Coxiella burnetii in ticks after a large outbreak of Q Fever. Zoonoses Public Health 2012, 59, 69-75.

49. Carvalho, C.L.; Lopes de Carvalho, I.; Zé-Zé, L.; Núncio, M.S.; Duarte, E.L. Tularaemia: A challenging zoonosis. Comp. Immunol. Microbiol. Infect. Dis. 2014, 37, 85-96.

50. Gehringer, H.; Schacht, E.; Maylaender, N.; Zeman, E.; Kaysser, P.; Oehme, R.; Pluta, S.; Splettstoesser, W.D. Presence of an emerging subclone of Francisella tularensis holarctica in Ixodes ricinus ticks from south-western Germany. Ticks Tick Borne Dis. 2013, 4, 93-100.

51. Michelet, L.; Delannoy, S.; Devillers, E.; Umhang, G.; Aspan, A.; Juremalm, M.; Chirico, J.; van der Wal, F.J.; Sprong, H.; Boye Pihl, T.P.; et al. High-throughput screening of tick-borne pathogens in Europe. Front. Cell. Infect. Microbiol. 2014, 4, 1-13.

52. Moutailler, S.; Valiente Moro, C.; Vaumourin, E.; Michelet, L.; Tran, F.H.; Devillers, E.; Cosson, J.F.; Gasqui, P.; Van, V.T.; Mavingui, P.; et al. Co-infection of Ticks: The Rule Rather Than the Exception. PLoS Negl. Trop. Dis. 2016, 10, 1-17.

53. Klitgaard, K.; Kjær, L.J.; Isbrand, A.; Hansen, M.F.; Bødker, R. Multiple infections in questing nymphs and adult female Ixodes ricinus ticks collected in a recreational forest in Denmark. Ticks Tick Borne Dis. 2019, 10, 1060-1065. 
54. Krause, P.J.; McKay, K.; Thompson, C.A.; Sikand, V.K.; Lentz, R.; Lepore, T.; Closter, L.; Christianson, D.; Telford, S.R.; Persing, D.; et al. Disease-Specific Diagnosis of Coinfecting Tickborne Zoonoses: Babesiosis, Human Granulocytic Ehrlichiosis, and Lyme Disease. Clin. Infect. Dis. 2002, 34, 1184-1191.

55. Estrada-Peña, A.; Ayllón, N.; de la Fuente, J. Impact of climate trends on tick-borne pathogen transmission. Front. Physiol. 2012, 3, 1-12.

56. Coipan, E.C.; Jahfari, S.; Fonville, M.; Maassen, C.B.; van der Giessen, J.; Takken, W.; Takumi, K.; Sprong, H. Spatiotemporal dynamics of emerging pathogens in questing Ixodes ricinus. Front. Cell. Infect. Microbiol. 2013, 4, 1-11.

57. Hovius, J.W.R.; De Wever, B.; Sohne, M.; Brouwer, M.C.; Coumou, J.; Wagemakers, A.; Oei, A.; Knol, H.; Narasimhan, S.; Hodiamont, C.J.; et al. A case of meningoencephalitis by the relapsing fever spirochaete Borrelia miyamotoi in Europe. Lancet 2013, 382, 658.

58. Coipan, C.E.; Van Duijvendijk, G.L.A.; Hofmeester, T.R.; Takumi, K.; Sprong, H. The genetic diversity of Borrelia afzelii is not maintained by the diversity of the rodent hosts. Parasit. Vectors 2018, 11, 1-7.

59. Szekeres, S.; Coipan, E.C.; Rigó, K.; Majoros, G.; Jahfari, S.; Sprong, H.; Földvári, G. Eco-epidemiology of Borrelia miyamotoi and Lyme borreliosis spirochetes in a popular hunting and recreational forest area in Hungary. Parasit. Vectors 2015, 8, 1-8.

60. Jahfari, S.; Fonville, M.; Hengeveld, P.; Reusken, C.; Scholte, E.J.; Takken, W.; Heyman, P.; Medlock, J.M.; Heylen, D.; Kleve, J.; et al. Prevalence of Neoehrlichia mikurensis in ticks and rodents from North-west Europe. Parasit. Vectors 2012, 5, 1-10.

61. Hodžić, A.; Alić, A.; Fuehrer, H.P.; Harl, J.; Wille-Piazzai, W.; Duscher, G.G. A molecular survey of vector-borne pathogens in red foxes (Vulpes vulpes) from Bosnia and Herzegovina. Parasit. Vectors 2015, 8, 1-7.

62. Kamani, J.; Baneth, G.; Mitchell, M.; Mumcuoglu, K.Y.; Gutiérrez, R.; Harrus, S. Bartonella species in bats (Chiroptera) and bat flies (Nycteribiidae) from Nigeria, West Africa. Vector Borne Zoonotic Dis. 2014, 14, 625-632.

63. Forsman, M.; Sandstrom, G.; Sjostedt, A. Analysis of $16 \mathrm{~S}$ ribosomal DNA sequences of Francisella strains and utilization for determination of the phylogeny of the genus and for identification of strains by PCR. Int. J. Syst. Bacteriol. 1994, 44, 38-46.

64. Alsaleh, A.; Pellerin, J.L.; Rodolakis, A.; Larrat, M.; Cochonneau, D.; Bruyas, J.F.; Fieni, F. Presence of an emerging subclone of Francisella tularensis holarctica in Ixodes ricinus ticks from south-western Germany. Comp. Immunol. Microbiol. Infect. Dis. 2011, 34, 355-360. 